\title{
Exploring the past through the present
}

\author{
Alexander T. Mikhailov \\ Developmental Biology Unit, Institute of Health Sciences, University of La Coruña, Campus de Oza, Building \\ “El Fortín”, Las Jubias Str. s/n, La Coruña, 15006, Spain
}

I am afraid that I don't know what the "river-of-knowledge" is. Also, I am not sure that "the past illuminates the future" although the lessons learned from history are sometimes used in the analysis of contemporary events in a given field of biological research.

The goal of my short account on Russian comparative embryology (Mikhailov 2012) was not to recapitulate the past, as important as that may be, but to trace underlying conceptual patterns that continued to shape evolutionary embryology research in Russia from the mid-nineteenth to mid-twentieth century. Inevitably, this allowed me to sketch the portraits of the founders of comparative and evolutionary embryology, Karl von Baer, Alexander Kowalevsky, and Illya Mechnikoff. (Both Kowalevsky and Mechnikoff were followers, not pupils of von Baer, and each one of them had a different style of thinking and reasoning as well as a different temperament.)

It was not my intention to create any impression of a substantial agreement or disagreement between Alexander Kowalevsky and Karl von Baer. As repeatedly noted, the importance of Kowalevsky's studies was recognized and appreciated by von Baer, who, nonetheless, did not accept that these findings could open up novel perspectives in the study of the origins of vertebrates (Blyakher 1955/1982; Vucinich 1988; Adams 2008).

Also, I am far from criticizing Margherita Raineri's treatment of Kowalevsky's studies, but it seems to me that the "von Baer versus Kowalevsky" contraposition (see Raineri 2009 and her present remark) needs a commentary. Despite its length, the following quotation from the book (1955) by Leonid Blyakher (a corresponding member of the International Academy of the History of Science) may counterbalance Raineri's outlook on von Baer's 1873 paper:

"The cause of his writing this paper was sensational. As Baer wrote, A. O. Kovalevsky discovered that ascidians, which in their adult condition are so strongly differentiated from vertebrates, at the beginning develop similarly to vertebrates. "If this conclusion," Baer stated, "could have been substantiated, the sensation would have been completely valid [...]." Baer then referred to the investigation of I. I. Mechnikov, "also an experienced embryologist," and in particular to the data of K. Kupffer [...]. Baer wrote, "the genetic relationship between Ascidiae and vertebrates indicates the importance of the results received. The factual data and Kovalevsky's interpretations concerning the coincidence of the development of ascidiae and vertebrates were confirmed and partially made more accurate $[\ldots . .$.$] . Baer cited$ after this only one negative treatment of Kovalevsky's discovery, and with characteristic honesty he drew attention to its groundlessness. Baer's objectivity stands out here more clearly, since he himself did not agree with the opinions of Kovalevsky, Kupffer, and Darwin." 
As Alexander Vucinich (1988) stresses, the respect was mutual:

"Mindful of von Baer's scholarly stature and advanced age, Kovalevskii chose not to defend himself publicly. This did not mean, however, that he was not unhappy with von Baer's criticism; in a letter to Mechnikov he stated that von Baer relied on outdated arguments, which showed only that "time has gone ahead of him."

There is a difference between discovering a new phenomenon and its conceptual interpretation: progress of science depends on revealing unexpected phenomena, while possible lines of explanation could be envisioned within different contextual frameworks. Kowalevsky discovered that the ascidian tadpole develops in a manner similar to what he described in Amphioxus and to that known to be the case for amphibians. In fact, the tadpole-like larva of most tunicates does share a basic body plan with vertebrate embryos including the dorsal neural tube and underlying notochord; thus tunicates became a gold mine for evolutionary developmental biologists as well as an unending source of surprises (reviewed in: Di Gregorio and Levine 1998; Satoh 2003; Lemaire et al. 2008; Horie et al. 2009; Lemaire 2011; Sasakura et al. 2012).

More broadly, I would like to quote Brian Hall's (2007) remark which echoes my concerns about exploring the roots of evo-devo:

"Out of the same facts of anatomy and development men of equal ability and repute have brought the most opposite conclusions. To take for instance the question of the ancestry of the Chordata $[. . . .$.$] , even if we neglect fanciful suggestions, there$ remain two wholly incompatible views as to the line of Vertebrate descent, each well supported and upheld by many. From the same facts opposite conclusions are drawn. Facts of the same kind will take us no future. The issue turns not on the facts but on the assumptions. Surely we can do better than this. Need we waste more efforts in these vain and sophistical disputes?"

As Raineri noted correctly in her commentary, von Baer "contrary to Mikhailov (2012), never was a professor of embryology at the University of Dorpat (Estonia);" in fact, he was a professor of zoology and professor of anatomy at the University of Königsberg (now Kaliningrad, Russia).

\section{References}

Adams, M. B. 2008. Kovalevsky, Aleksandr Onufrievich. In: Complete Dictionary of Scientific Biography (available at http://www.encyclopedia.com).

Blyakher, L. Y. 1955/1982. History of Embryology in Russia from the Middle of the XVIII to the Middle of the XIX Century. The Al Ahram Center for Sci. Transl., Washington, pp. 480-482.

Di Gregorio, A., and Levine, M. 1998. Ascidian embryogenesis and the origins of the chordate body plan. Curr. Opin. Genet. Dev. 8: 457-463.

Hall, B. K. 2007. Tapping many sources: the adventitious roots of evo-devo in the nineteenth century. In M. D. Laubichler and J. Maienschein (eds.). From Embryology to Evo-Devo: A History of Developmental Evolution. The MIT Press, Cambridge, pp. 486-487.

Horie T., Nakagawa, M., Sasakura, Y., and Kusakabe, T. G. 2009. Cell type and function of neurons in the ascidian nervous system. Dev. Growth Differ. 51: 207-220.

Lemaire, P. 2011. Evolutionary crossroads in developmental biology: the tunicates. Development 138: 21432152.

Lemaire, P., Smith, W. C., and Nishida, H. 2008. Ascidians and the plasticity of the chordate developmental program. Curr. Biol. 18: R620-R631.

Mikhailov, A. T. 2012. Russian comparative embryology takes form: a conceptual metamorphosis toward "evo-devo." Evol. Dev. 14: 9-19.

Raineri, M. 2009. On some historical and theoretical foundations of the concept of chordates. Theory Biosci. 128: 53-73.

Sasakura, Y., Mita, K., Ogura, Y., and Horie, T. 2012. Ascidians as excellent chordate models for studying the development of the nervous system during embryogenesis and metamorphosis. Dev. Growth Differ. 54: 420-437.

Satoh, N. 2003. The ascidian tadpole larva: comparative molecular development and genomics. Nat. Rev. Genet. 4: 285-295.

Vucinich, A. 1988. Darwin in Russian Thought. Univ. California Press, Berkeley and Los Angeles, pp. 5758. 